получении товара наличными, или безналичными с помощью банковской картой или электронными деньгами (QIWI Кошелёк). Встречаются интернет-магазины, где, сначала производится оплата в полном объеме, и только потом отправка товара получателю.

8. Выбор доставки. Так же, как и выбор способа оплаты у покупателя есть и право выбрать удобный для него способ доставки, используя почту, заказать курьера с доставкой товара прямо до квартиры или же самостоятельно забрать товар из офиса интернет-магазина. В последнем случае доставка будет бесплатной.

Таким образом, проанализировав нормативно-правовую базу и практику применения договора розничной купли-продажи в сети «Интернет» можно указать как преимущества, так и недостатки осуществления данного договора. Развитие цифровых технологий не стоит на месте. Реализация договора розничной купли-продажи в сети «Интернет» прочно вошла в повседневную жизнь практически каждого человека.

Торговля таким способом является очень удобной, т.к. можно, не покидая дома, места работы или учёбы приобрести тот или иной товар. Дистанционная торговля получает все большее распространение в РФ, поэтому требует дополнений и доработок нормативно-правовых актов, регламентирующих договор розничной купли-продажи.

В следствии высоких темпов развития электронной торговли законодатель улучшает нормативную базу, чему свидетельствуют изменения от 1 января 2021 года, закрепляющие правила дистанционной торговли - как стремительно развивающемуся, новому направлению в процессе реализации договора розничной купли-продажи в условиях развития цифровых технологий.

$$
* * *
$$

1. Постановление Правительства РФ от 31.12.2020 N 2463 "Об утверждении Правил продажи товаров по договору розничной купли-продажи, перечня товаров длительного пользования, на которые не распространяется требование потребителя о безвозмездном предоставлении ему товара, обладающего этими же основными потребительскими свойствами, на период ремонта или замены такого товара, и перечня непродовольственных товаров надлежащего качества, не подлежащих обмену, а также о внесении изменений в некоторые акты Правительства Российской Федерации"// КонсультантПлюс: справочная правовая система - Режим доступа http://www.consultant.ru

2. Проект «Стратегия развития электронной торговли на период до 2025г.» // [Электронный ресурс] //

https://minpromtorg.gov.ru/docs/\#!proekt_strategiya_razvitiya_elektronnoy_torgovli_v_rossiyskoy_feder acii_na_period_do_2025_goda

3. Марчук, М.А Правовое регулирование дистанционной торговли в законодательстве России и Евросоюза. // Ленинградский юридический журнал. -2013. -№4 [Электронный ресурс] // http://cyberleninka.ru/

\title{
Крутских А.C. \\ Актуальные проблемы применения ст. 15.34.1 КОАП РФ в случае необоснованного отказа от заключения публичного договора страхования
}

Московский государственный юридический университет им. О.Е. Кутафина

(Россия, Москва)

doi: $10.18411 / \mathrm{j}-06-2021-218$

\section{Аннотация}

В статье проведен анализ правоприменительной практики применения ст. 15.34.1 КоАП РФ, который позволил обобщить некоторые актуальные виды проблем реализации этих норм при отказе страховой организации от заключения публичного договора: организационно-правовые проблемы незнания, неисполнения правоприменительным субъектом требований действующего законодательства и 
позиций судебной практики; организационно-коммуникационные проблемы отсутствия обратной связи при взаимодействии потребителя со страховщиком; технико-правовые проблемы отсутствия у страховщиков надежной и бесперебойной программнотехнологической базы для заключения публичных электронных страховых договоров.

Ключевые слова: публичный договор страхования, ОСАГО, административная ответственность, отказ от заключения публичного страхового договора, электронная форма договора.

\section{Abstract}

The article analyzes the law enforcement practice of applying Article 15.34 .1 of the Administrative Code of the Russian Federation, which allowed us to summarize some current types of problems of implementing these norms when an insurance company refuses to conclude a public contract: organizational and legal problems of ignorance, non-compliance by the law enforcement entity with the requirements of current legislation and the positions of judicial practice; organizational and communication problems of the lack of consumer feedback with the insurer; technical and legal problems of insurers ' lack of a reliable and uninterrupted software and technology base for concluding public electronic insurance contracts.

Keywords: public insurance contract, CTP, administrative liability, refusal to conclude a public insurance contract, electronic contract form.

Важность исследования вопросов практической реализации правового механизма административной ответственности за необоснованный отказ страховой организации от заключения публичного договора страхования определяется рядом актуальных проблем оформления такой сделки в электронной форме.

В частности, в силу бурного развития информационных технологий законодатель не успевает учесть все новейшие организационно-технические аспекты дистанционного заключения публичного страхового договора, что приводит к соответствующим правовым конфликтам и аргументирует важность постоянного мониторинга правоприменительной практики с целью разработки необходимых правовых средств оформления и реализации электронных страховых договоров, а также эффективных средств привлечения виновных к ответственности. При этом в последние годы отмечается рост негативных случаев отказа от заключения обязательных страховых публичных договоров гражданской ответственности транспортных владельцев (далее - ОСАГО), сопровождающихся массовым характером в большинстве регионов России, когда сотрудники страховых организаций, страховые агенты отказываются заключать ОСАГО либо требуют от потребителя при заключении этого договора дополнительно застраховать другие риски [12].

В этой связи стоит отметить, что в Российской Федерации в текущий момент насчитывается 61 вид вмененного (обязанность по осуществлению которого возложена на страхователя в силу закона) страхования: 31 вид определяется страхованием ответственности, 3 вида - страхованием имущества, 27 видов - здоровья, жизни определенных категорий граждан [13].

За 2020 год в система ГАС «Правосудие» зарегистрировано только 9 судебных решений о привлечении к административной ответственности за нарушение ст. 15.34.1 КоАП РФ [2], из них Центральным районным судом г. Новосибирска вынесено 4 решения, судами Алтайского края - 3 решения, судами Казани и Красноярка - по 1 решению, которые не включают вопросов, связанных с электронным оформлением страховых договоров. За 2019 год российскими судами было вынесено 32 таких решения, из них в 6 рассматривались нарушения в рамках страховых договоров в электронной форме, в 2018 году - 52, из них - 7 по электронным договорам, в 2017 году - 218 (24 по электронным договорам), в 2016 году - 246 (9), в 2015 - 424 (11) [11]. 
То есть необходимость исследования актуальных проблем применения ст. 15.34.1 КоАП РФ из-за необоснованного отказа от заключения публичного страхового договора, особенно договоров ОСАГО, обусловлена активным развитием вмененного страхования, существенным снижением числа привлеченных лиц к ответственности по нормам ст. 15.34.1 КоАП РФ, одной из причин которого представляются пробелы действующего законодательства в цифровой сфере договорных отношений.

Рассматриваемые правовые проблемы применения ст. 15.34.1 КоАП РФ отражены в соответствующей судебной практике.

Так, при разрешении административного дела № 12-185/2019 [8] суд Ленинского района г. Чебоксары отказал заявителю в пересмотре решения Банка России по нарушению АО «МАКС» (далее - Общество). При этом суд отметил:

- согласно п. 22 Порядка обмена электронной информацией в рамках заключения в электронном виде договора ОСАГО (далее - е-ОСАГО) [5] страховщик в лице Общества обязан обеспечить надежное, бесперебойное функционирование собственных информационных систем, средств связи с целью информационного обмена с потребителем на стадии заключения договора ОСАГО; поэтому отсутствие технической возможности взаимодействия с потребителем не может быть основанием для отказа в заключении анализируемого договора;

- в материалах административного дела имеются другие договоры ОСАГО, которые заключены Обществом в день отказа в заключении спорного договора, что подтверждает наличие фактической и юридической возможностей для заключения Обществом электронного договора ОСАГО в спорной ситуации;

- факт отсутствия выплаты страховой премии потребителем в день обращения к Обществу как страховщику с соответствующим заявлением на заключение договора е-ОСАГО также не может быть выступать основанием отказа в заключении договора е-ОСАГО, поскольку невыплата страховой премии представляется не причиной, а следствием полученного отказа Общества от заключения е-ОСАГО;

- при спорных вопросах согласно п. 7 постановления Пленума ВС РФ № 58 от 2017 года [6] следует учитывать, что договор ОСАГО должен соответствовать требованиям Федерального закона № 40-Ф3 от 2002 года [10], другим действующим подзаконным правовым актам; согласно п. 1.6. Правил ОСАГО [4] Общество не может требовать от потребителя оригиналы документов, если ранее с ним был заключен договор страхования и отсутствуют данные о неверных сведениях в предоставленных потребителем копиях документов, электронных документах;

— из содержания п. 7 ст. 15 Федерального закона № 40-Ф3 от 2002 года следует, что Общество обязано в день обращения потребителя вручить ему полис е-ОСАГО или выдать письменный мотивированный отказ в заключении этого договора, о чем должны быть проинформированы Банк России, профессиональное объединение страховщиков.

Анализ отмеченного судебного решения позволяет обозначить организационноправовую проблему реализации ст. 15.34.1 КоАП РФ при отказе страховой организации от заключения публичного договора, которая определяется незнанием, неисполнением правоприменительным субъектом требований действующего законодательства и позиций судебной практики. 
В другом судебном решении по делу №12-556/2017 [9] о пересмотре решения Банка России по нарушению ОАО «АльфаСтрахование» (далее - Общество) ст. 15.34.1 Центральный районный суд г. Новосибирска установил:

— заявитель С. не смог оформить договор е-ОСАГО на сайте Общества изза невозможности выбора соответствующего года выпуска приобретенного автомобиля Toyota (1983 год) на веб-странице Общества, отражающей процедуры заключения е-ОСАГО;

— указанная техническая причина не принята компетентным лицом Банка России в качестве основания привлечения Общества к ответственности по ст. 15.34.1 КоАП РФ, что послужило основанием к обжалованию С. в суде принятого решения Банка России;

- из материалов дела и пояснений представителей Общества следует, что C. не получал отказ в заключении публичного электронного договора ОСАГО, поскольку ресурсы веб-сайта Общества предоставляли ему посредством указания марки автомобиля на веб-сайте «другое транспортное средство» надлежащим оформить электронный договор страхования с учетом года выпуска приобретенного автомобиля Toyota (1983 год); при этом отмечено, что С. обращался с аналогичным заявлением в Железнодорожный районный суд г. Новосибирска, где было отказано в удовлетворении его требований, поскольку отказа он не получал и техническая возможность заключения электронного договора ОСАГО подтверждалась;

— Центральный районный суд г. Новосибирска в этом случае отказал С. в пересмотре решения Банка России о привлечении Общества к ответственности по ст. 15.34.1 КоАП РФ и отметил, что отказ от заключения е-ОСАГО в рассмотренной спорной ситуации С. не получал и обладал технической возможностью онлайн-оформления такого договора.

Из указанного примера проблемного заключения публичного договора еОСАГО можно выделить организационно-коммуникационную правовую проблему реализации ст. 15.34.1 КоАП РФ при отказе страховой организации от заключения публичного договора, заключающуюся в недопонимании потребителем всех технических условий онлайн-оформления такого договора. Устранение обозначенной коммуникационной проблемы предполагает установление обязанности страховой компании извещать потребителя доступным способом о всех особенностях заключения е-ОСАГО и иного страхового договора в электронной форме.

Другая категория проблем исполнения ст. ст. 15.34.1 КоАП РФ обусловлена технико-правовыми аспектами развития информационных технологий, сопровождающегося различными поломками, выходом из строя программного и прочего технического обеспечения взаимодействия страховщика с потребителем с целью заключения е-ОСАГО. Так, в апелляционном арбитражном постановлении по делу № A40-279289/2018 [7] отмечается, что правомерным основанием для привлечения страховщика к ответственности по ст. 15.34.1 КоАП РФ стали нарушения требований действующего законодательства:

- установленный п. 3 ст. 426, п. 4 ст. 445 ГК РФ [1] запрет на отказ общества-страховщика от заключения публичного договора ОСАГО, если имеется возможность заключить этот договор;

— обозначенное в п. 7.2 ст. 15 Федерального закона № 40-ФЗ от 2002 года [3] право заключения договора ОСАГО в электронной форме с учетом требований этого закона; 
— предусмотренную п. 1.1 ст. 22 Федерального закона № 40-Ф3 от 2002 года обязанность общества-страховщика обеспечивать непрерывность, бесперебойность функционирования собственных официальных вебсайтов для заключения договоров е-ОСАГО в соответствии с Правилами ОСАГО [4]; и т.д.

При этом общество-страховщик не предоставило доказательств невозможности соблюдения указанных требований законодательства.

Анализ обозначенного судебного решения позволяет указать на техникоправовую проблему реализации ст. 15.34.1 КоАП РФ при отказе страховой организации от заключения публичного договора, которая обусловлена отсутствием у страховщиков достаточной программно-технологической базы для исполнения требований законодательства о надежности и бесперебойности функционирования собственных официальных веб-сайтов для заключения договоров е-ОСАГО. Минимизация этой проблемы предопределяет важность установления единых техническо-правовых требований к веб-инструментам, с помощью которых осуществляется заключение электронных страховых договоров, в частности е-ОСАГО.

Таким образом, на примере изученных судебных решений по спорным вопросам заключения е-ОСАГО можно выделить некоторые актуальные виды проблем реализации ст. 15.34.1 КоАП РФ при отказе страховой организации от заключения публичного договора:

1) организационно-правовые проблемы, связанные с незнанием, неисполнением правоприменительным субъектом требований действующего законодательства и позиций судебной практики, которые решаются регулярным изучением соответствующих документов и реализацией их на практике;

2) организационно-коммуникационные проблемы, заключающиеся в отсутствии постоянной обратной связи потребителя со страховщиком, в недопонимании потребителем всех технических условий онлайноформления публичного страхового договора, которые устраняются установлением обязанности страховой компании извещать потребителя доступным способом о всех особенностях заключения е страхового договора в электронной форме;

3) технико-правовые проблемы, обусловленные отсутствием у страховщиков надежной и бесперебойно программно-технологической базы для заключения рассматриваемых публичных е-договоров, что предопределяет важность установления единых техническо-правовых требований к соответствующим веб-инструментам страховщиков.

$$
* * *
$$

1. Гражданский кодекс Российской Федерации (часть первая) от 30.11.1994 № 51-ФЗ (ред. от 09.03.2021) // Собрание законодательства РФ. 1994. № 32. Ст. 3301.

2. Кодекс Российской Федерации об административных правонарушениях от 30.12.2001 № 195-Ф3 (ред. от 30.04.2021) // Собрание законодательства РФ. 2002. № 1 (ч. 1). Ст. 1.

3. Федеральный закон от 25.04.2002 № 40-ФЗ (ред. от 08.12.2020) "Об обязательном страховании гражданской ответственности владельцев транспортных средств" // Собрание законодательства РФ. 2002. № 18. Ст. 1720.

4. Положение Банка России от 19.09.2014 № 431-П (ред. от 22.09.2020) "О правилах обязательного страхования гражданской ответственности владельцев транспортных средств" // Вестник Банка России. № 93. 8 октября 2014.

5. Указание Банка России от 14.11.2016 № 4190-У (ред. от 22.09.2020) "О требованиях к использованию электронных документов и порядке обмена информацией в электронной форме при осуществлении обязательного страхования гражданской ответственности владельцев транспортных средств" // "Вестник Банка России", N 115-116, 30.12.2016. 
6. Постановление Пленума Верховного Суда РФ от 26.12.2017 N 58 "О применении судами законодательства об обязательном страховании гражданской ответственности владельцев транспортных средств" // Бюллетень Верховного Суда РФ. № 4, апрель, 2018.

7. Постановление Девятого арбитражного апелляционного суда от 14.06.2019 N 09АП-23153/2019 по делу N A40-279289/2018 [Электронный pecypc], URL: https://kad.arbitr.ru/ (дата обращения 11.05.2021).

8. Решение по делу №12-185/2019 Ленинского районного суда г. Чебоксары от 11 марта 2019 года. [Электронный ресурс], URL: https://bsr.sudrf.ru/bigs/portal.html (дата обращения 11.05.2021).

9. Решение по делу №12-556/2017 Центрального районного суда г. Новосибирска от 30 ноября 2017 года. [Электронный ресурс], URL: https://bsr.sudrf.ru/bigs/portal.html (дата обращения 11.05.2021).

10. Федеральный закон от 25.04.2002 № 40-Ф3 (ред. от 08.12.2020) "Об обязательном страховании гражданской ответственности владельцев транспортных средств" // Собрание законодательства РФ. 2002. № 18. Ст. 1720.

11. Информация портала ГАС «Правосудие». [Электронный pecypc], URL: https://bsr.sudrf.ru/bigs/portal.html (дата обращения 11.05.2021).

12. Пояснительная записка проекта Федерального закона N 596465-7 "О внесении изменений в статью 15.34.1 Кодекса Российской Федерации об административных правонарушениях (в части увеличения меры ответственности за необоснованный отказ от заключения публичного договора страхования либо навязывание дополнительных услуг при заключении договора обязательного страхования)" (ред., внесенная в ГД ФС РФ, текст по состоянию на 28.11.2018). [Электронный pecypc], URL: http://asozd2.duma.gov.ru/main.nsf/(Spravka)?OpenAgent\&RN=596465-7 (дата обращения 11.05.2021).

13. Текущее состояние страхового рынка в Российской Федерации в сегменте вмененного страхования. 2021. [Электронный реска. URL: https://cbr.ru/Content/Document/File/118732/report_insurance_20210219.pdf (дата обращения 11.05.2021).

Крюков А.В.

Уголовно-правовые и социальные аспекты молодежного экстремизма

Санкт-Петербургского университета МВД России (Россия, Санкт-Петербург)

doi: 10.18411/lj-06-2021-219

\section{Аннотация}

В данной статье предпринята попытка рассмотрения социальнопсихологических и уголовно-правовых аспектов возниковения молодежного экстремизма, как сложного социального феномена, включающего в себя различные формы проявления радикализма. Актуальность проблемы отражает количество вынесенных в 2020 году обвинительных приговоров за экстремистские высказывания и призывы. В статье определены современные проблемы ведущие молодежь к участию в экстремистских организациях и предложены меры противодействия экстремизму с точки зрения автора статьи.

Ключевые слова: Молодежный экстремизм, радикализм, агрессия, «социальная скука», межнациональная вражда, патриотическое воспитание.

\section{Abstract}

This article attempts to consider the socio-psychological and criminal-legal aspects of the emergence of youth extremism as a complex social phenomenon that includes various forms of radicalism. The urgency of the problem reflects the number of convictions issued in 2020 for extremist statements and appeals. The article identifies modern problems that lead young people to participate in extremist organizations and suggests measures to counter extremism from the point of view of the author of the article.

Keywords: Youth extremism, radicalism, aggression, "social boredom", interethnic hostility, patriotic education. 